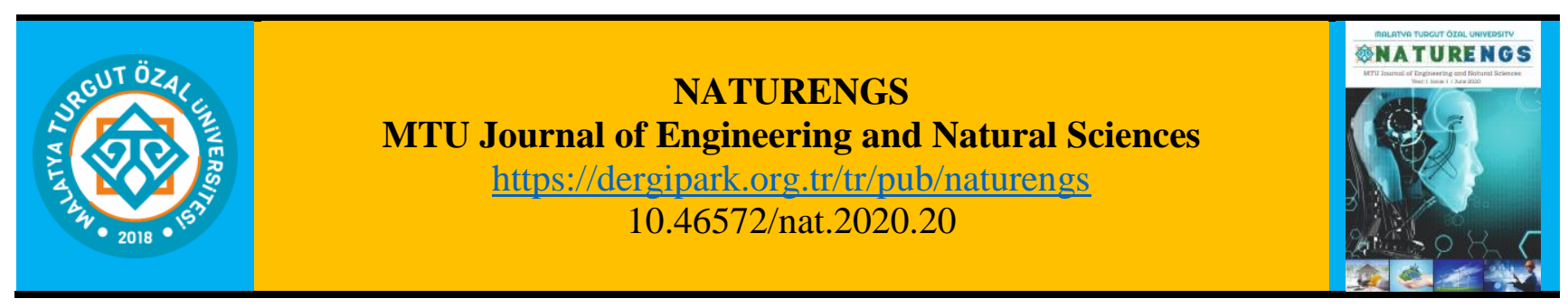

\title{
Obtaining Activated-Carbon from Zivzik (Siirt) Pomegranate Waste by Chemical Activation and Model Dye Adsorption
}

\author{
Ali Ender KUYUCU ${ }^{*}$, Ahmet SELÇUK ${ }^{2}$, Yunus ÖNAL ${ }^{3}$ \\ ${ }^{1}$ Chemistry, Faculty of Science, Yüzüncü Yıl University, Van, Turkey \\ ${ }^{2}$ Sciences and Mathematics Education, Faculty of Education, Yüzüncü Y1l University, Van, Turkey \\ ${ }^{3}$ Department of Chemical Engineering, Faculty of Engineering, Inönü University, Malatya, Turkey
}

(Received: 25.12.2020; Accepted: 30.12.2020)

\begin{abstract}
In this study, activated carbon, obtained from Zivzik Pomegrate (Siirt-TURKEY), has been used as adsorbent matter. The activated-carbon has been prepared with chemical activation using $\mathrm{ZnC1}_{2}$. $\mathrm{BET}_{\text {surface }}$ area has been measured as $1513.05 \mathrm{~m}^{2} / \mathrm{g}$. Methylene Blue and Crystal Violet have been used as dyestuffs. It has been investigated the effect of initial $\mathrm{pH}$, initial dye concentration and temperature on adsorption. Four different initials concentrations have been used for both dyestuffs. It has been observed that the initial $\mathrm{pH}$ does not affect the adsorption capacity. The compatibility with four different adsorption isotherms has been investigated and it is approved that it fits the Langmuir adsorption isotherm. For both dyes; $\mathrm{R}_{\mathrm{L}}$ value, which is the dimensionless separation factor found using $\mathrm{K}_{\mathrm{L}}$ value from Langmuir parameters, was found to be 0.001 . This result shows that the adsorption process is efficient. Also, it was seen that the correlation factor $\mathrm{R}^{2}$ for both dyes calculated from the graph drawn according to the Langmuir isotherm has a high value such as 0,999. Three different kinetic models (the pseudo first order model, the pseudo second order model and the Elovich equation) have been investigated by doing experimental studies at three different temperatures with different initial concentrations. Correlation coefficient $\mathrm{R}^{2}$ is; for Methylene Blue 0.99 and for Crystal Violet 0.99 . Since the $\mathrm{q}_{\mathrm{e}}$ values calculated with the experimental $\mathrm{q}_{\mathrm{e}}$ values are compatible with each other, it was observed that our study is more suitable for the Pseudo 2nd Order Kinetic model. The entropy $\left(\Delta \mathrm{S}^{\circ}\right)$ values are $51.717 \mathrm{~J} / \mathrm{molK}$ for Methylene Blue and 70.817 $\mathrm{J} / \mathrm{molK}$ for Crystal Violet, respectively. The positive values of $\Delta \mathrm{S}^{\circ}$ reflect the affinity of adsorbent material towards Methylene Blue and Crystal Violet. In addition, it has been observed that adsorption is reversible and endothermic.
\end{abstract}

Keywords: Adsorption, Activated carbon, Dye, İsotherm, Kinetic.

\section{INTRODUCTION}

Textile industry wastewaters contain a wide variety of organic materials, heavy metals, dissolved salts, color, turbidity, and discharging to the external environment at different $\mathrm{pH}$ 's and require first degree treatment. Uncontrolled delivery of textile industry waste water to the environment without treatment is dangerous for both human health and the ecosystem [1].

Many methods and materials have been developed by scientists to remove pollution due to increasing environmental pollution. One of these methods is the adsorption technique. 
Studies in the field of adsorption have been showing a rapid increase in proportion with environmental awareness since the 1970s. In this context, adsorption is a very good technique to remove pollutants and is widely used in gas and liquid phase applications.

In addition to removing contaminants, adsorption has become an important separation technique with the potential for regeneration, recovery and recycling of adsorbent materials [2] Therefore, the development of new adsorption systems and porous materials constitutes great importance. Active carbon is one of the most important of these porous materials that have been researched extensively [3].

Activated carbons are frequently used in industry and daily life for various purposes such as environmental pollution control, bleaching, deodorization due to their high porosity and good adsorbent properties. Commercially activated carbons are obtained by activating the carbons obtained from wood, peat, lignite, coal, charcoal, bone, coconut shell, rice husk, nut shell and oil products through various processes [4].

Activated carbon is commonly defined as an amorphous material with high surface area and high porosity, which is generally prepared from carbon-based materials in a waste state [5]. There has not been a formula showing the active carbon structure yet. This structure can be used as a good absorbent owing to its high surface area and high porosity. In addition, the pore volumes of activated carbons vary between 3 angstroms and several thousand angstroms, so they have high adsorption capacity. Generally, organic-based activated carbons contain 87-97\% carbon and the remaining part consists of oxygen, sulfur, nitrogen and hydrogen. Also, this ratio varies depending on the material to be synthesized activated carbon [6]. Although activated carbon is the oldest among the adsorbents available [7], it is still the most used material in the industry. Therefore, studies continue to prepare activated carbon with the most appropriate method and to understand its pore structure [8].

Different processes are used for the preparation of activated carbon. In the physical activation method, raw materials, such as $\mathrm{CO}_{2}, \mathrm{~N}_{2}$ or water vapor, are activated at $700-1100{ }^{\circ} \mathrm{C}$ to produce activated carbon. Whereas, during the process of chemical activation carbonization is conducted at $400-900{ }^{\circ} \mathrm{C}$ in the presence of a chemical agent (e.g., $\mathrm{ZnCl}_{2}, \mathrm{KOH}, \mathrm{K}_{2} \mathrm{CO}_{3}, \mathrm{H}_{3} \mathrm{PO}_{4}$ or $\mathrm{H}_{2} \mathrm{SO}_{4}$ ) [9].

In this study, Zivzik pomegranate waste was used as a raw material in preparing activated carbon.

According to pomegranate production ranking between countries; Iran first, India second and Turkey ranks third. Pomegranate is grown in the coastline of the Aegean and Mediterranean Regions and the Southeastern Anatolia Region in our country. According to statistical data, pomegranate production is carried out in 48 cities in Turkey. In terms of pomegranate production amounts by cities; Antalya 71, Muğla 22, Denizli 13, Mersin 11, Gaziantep 8,8 and Aydın stand out with 8,5 thousand tons. The pomegranate production ranking of the Southeastern Anatolia Region (GAB) provinces as of 2009 is, Gaziantep is the first, Sanliurfa is the second and Siirt is the third [10].

Zivzik pomegranate wastes are dried in the laboratory and they have been activated by chemical activation using $\mathrm{ZnCl}_{2}$. The activation temperature was $800{ }^{\circ} \mathrm{C}$ and it has been activated for 1 hour. Methylene blue and Crystal violet have been used as model dyes in adsorption experiments. 


\subsection{Kinetic parameters of adsorption}

Several kinetic models have been put forward to determine what role the mechanism characterizing the adsorption process plays. In this study, Pseudo 1st and 2nd order kinetic equations and Elovich equation are used [11-16].

The pseudo-first-order equation is expressed as

$\frac{d q_{t}}{d t}=k_{1}\left(q_{e}-q_{t}\right)$

The integrated form of Eq. (1) becomes:

$\log \left(q_{e}-q_{t}\right)=\log q_{e}-\frac{k_{1}}{2.303} t \quad$ where $q_{e}$ and $q_{t}$ are amounts of dye adsorbed $(\mathrm{mg} / \mathrm{g})$ at equilibrium and time $t(\mathrm{~min})$, respectively, and $k_{1}$ is the rate constant os pseudo-first-order ( $\mathrm{min}^{-}$ $\left.{ }^{1}\right)$

The pseudo-second-order kinetic model of Ho and McKay is

$\frac{d q_{t}}{d t}=k_{2}\left(q_{e}-q_{t}\right)^{2}$

The integrated form of Eq.(2) becomes:

$\frac{t}{q_{t}}=\frac{1}{k_{2} q_{e}^{2}}+\frac{1}{q_{e}} t$

Where $k_{2}$ is the rate constant of pseudo-second-order adsorption $(\mathrm{g} /(\mathrm{mg} \min ))$ and $h=\mathrm{k}_{2} \mathrm{q}^{2}$, where $\mathrm{h}$ is the initial adsorption rate $(\mathrm{mg} / \mathrm{g} \mathrm{min})$.

The Elovich equation is given as follows:

$\frac{d q_{t}}{d t}=\alpha \cdot e^{-\beta \cdot q} t$

Where $\alpha$ is the initial rate $(\mathrm{mg} / \mathrm{g} \min )$ because ( $\mathrm{dq}_{\mathrm{t}} / \mathrm{dt}$ ) approaches $\alpha$ when $\mathrm{q}_{\mathrm{t}}$ approaches zero, and the parameter $\beta$ is related to the extent of surface coverage and activation energy for chemisorptions $(\mathrm{g} / \mathrm{mg})$.

Given that $\mathrm{q}_{\mathrm{t}}=0$ at $\mathrm{t}=0$, integrated form of Eq. (3) is

$q_{t}=\frac{1}{\beta} \ln \alpha \beta+\frac{1}{\beta} \ln t$ 


\section{MATERIAL AND METHODS}

\subsection{Materials}

Two dyes were used in the study. The dyes, Methylene Blue (MB) (Chemical Formula = $\mathrm{C}_{16} \mathrm{H}_{18} \mathrm{~N}_{3} \mathrm{SCl}, \mathrm{MW}=319.85 \mathrm{~g} / \mathrm{mol}, \lambda_{\max }=660 \mathrm{~nm}$ ) was supplied by Merck; Crystal Violet $(\mathrm{CV})$ (Chemical Formula $=\mathrm{C}_{25} \mathrm{~N}_{3} \mathrm{H}_{30} \mathrm{Cl}, \mathrm{MW}=407.979 \mathrm{~g} / \mathrm{mol}, \lambda_{\max }=594 \mathrm{~nm}$ ) was supplied by Merck. One thousand milligrams per liter of stock solution was prepared by dissolving the required amount of dye in double distilled water. Working solutions of the desired concentrations were obtained by successive dilutions.

\subsection{Preparation of activated carbon}

Activated carbon used as an adsorbent in experimental studies was obtained by subjecting Zivzik Pomegranate to the carbonization process in a tubular reactor after the chemical activation process.

In the first step; dried Zivzik Pomegranate waste has been dried in an oven by mixing with $\mathrm{ZnCl}_{2}$ in weight of 1:1 with a sufficient amount of water. The dried mixture has been activated in a nitrogen atmosphere in a tubular reactor in a tubular furnace. The activation process has been carried out by keeping under nitrogen atmosphere $(100 \mathrm{ml} / \mathrm{min})$ at $10^{\circ} \mathrm{C} / \mathrm{min}$ at a heating rate of $800{ }^{\circ} \mathrm{C}$ for 1 hour at a maximum temperature. The sample has been taken from the oven cooled to room temperature.

In the second stage, enough $0.5 \mathrm{~N} \mathrm{HCl}$ has been added to the sample taken after activation and boiled on the heater. The sample has filtered until it is sure that no chloride ions are left in the pure water. A chlorine ion test has been done with $\mathrm{AgNO}_{3}$. After the washing process, the activated carbon has been dried in the oven at $105{ }^{\circ} \mathrm{C}$ for 24 hours. After grinding and sifting processes, activated carbon has been separated by waiting in a desiccator to be used in experimental studies.

\subsection{Instrumentation}

A Tri Star 3000 ( Micromeritics, USA) surface analyzer was used to measure nitrogen adsorption isotherm at $77 \mathrm{~K}$ in the range of relative pressure $10^{-6}$ to 1 . Before measurement, the sample was degassed at $300^{\circ} \mathrm{C}$ for $2 \mathrm{~h}$. The BET surface area, total surface area and volume of the total surface were measured by the surface analyzer.

The spectrophotometric determination of dyes was done on a Boeco UV - vis spectrophotometer (model UV - S22, Germany).

\subsection{Adsorption experiments}

In studies that the effect of temperature and mixing time on adsorption was investigated, the solutions prepared as $200 \mathrm{ppm}, 400 \mathrm{ppm}, 600 \mathrm{ppm}$ and $800 \mathrm{ppm}$ by diluting from $1000 \mathrm{ppm}$ stock solution. Activated carbon was added 0.1 gram and prepared as $500 \mathrm{ml}$ solutions in 1000 $\mathrm{ml}$ beakers. It was mixed in the water bath at $25^{\circ} \mathrm{C}, 35^{\circ} \mathrm{C}$ and $45^{\circ} \mathrm{C}$. The moment when adsorbents were added to the solution was accepted as $\mathrm{t}=0$ and samples were taken at time intervals of $1,3,5,7,9,13,17,23,30,40,50,60,70,90$ and 120 minutes. 


\section{RESULTS AND DISCUSSION}

\subsection{Characterization of the prepared activated carbon}

Activated carbon surface measurements were made by BET device. Its total surface area, total surface volume and BET surface area were measured as $429,044 \mathrm{~m}^{2} / \mathrm{g}, 0,59232 \mathrm{~cm}^{3} / \mathrm{g}$ and $1513,05 \mathrm{~m}^{2} / \mathrm{g}$, respectively.

\subsection{Effect of temperature on adsorption}

In order to examine the effect of temperature on the adsorption mechanism, both dyes (Methylene Blue - Crystal Violet) were prepared in $1000 \mathrm{ml}$ of solution using $0.1 \mathrm{~g}$ of activated carbon at three different temperatures and mixed for the equilibrium period (1 hour). Results are shown in Figure 1 and Figure 2. As can be seen from the figures, similar graphics have emerged for both dyestuffs. As can be seen from the graphics, dye removal increased with the increase in temperature. This means that the adsorption mechanism is endothermic.

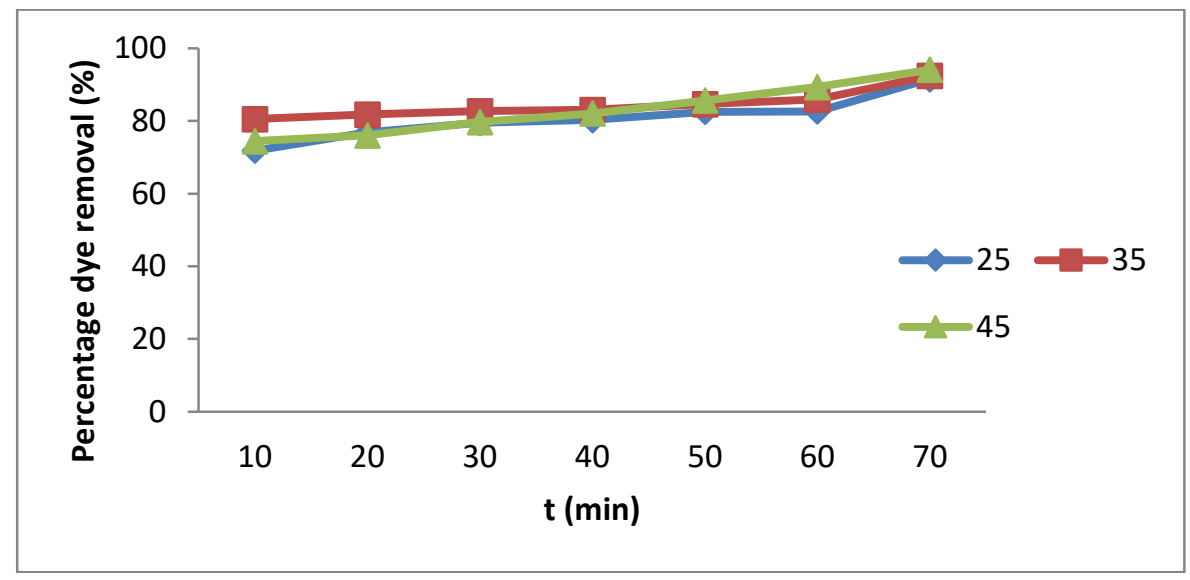

Figure 1. Effect of contact time and temperature on the adsorption of MB

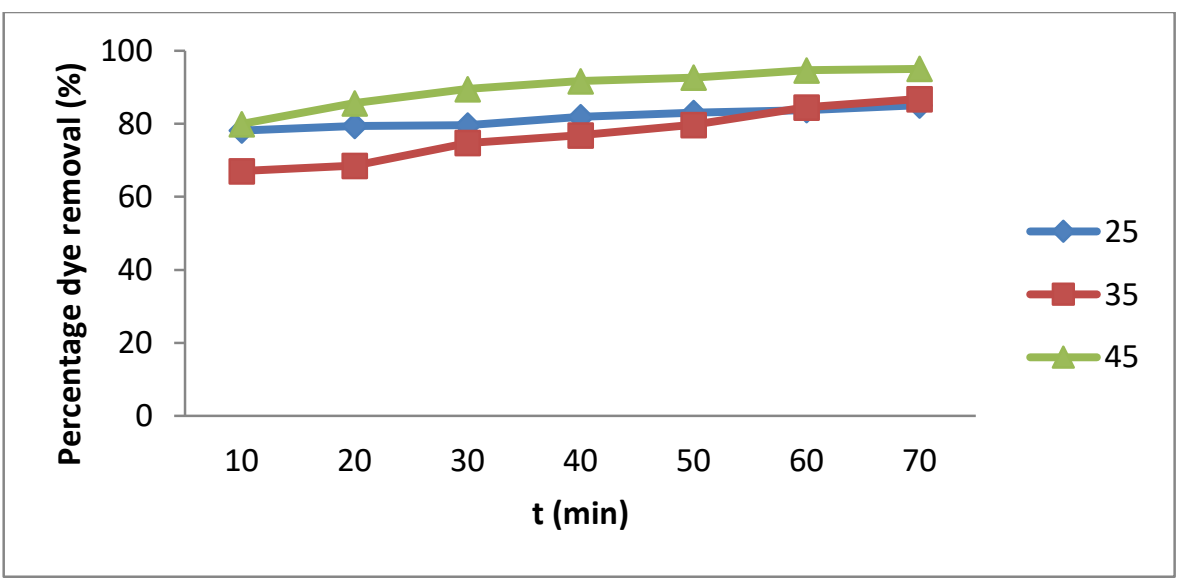

Figure 2. Effect of contact time and temperature on the adsorption of $\mathrm{CV}$ 
Three basic kinetic models were used for adsorption kinetics. The equality giving the best fit was determined by looking at the regression coefficient $\left(\mathrm{R}^{2}\right)$. Methylene Blue and Crystal Violet dyestuffs used in experiments to examine adsorption kinetics at different time intervals $(\mathrm{C} 0=$ $200 \mathrm{mg} / \mathrm{L}, 400 \mathrm{mg} / \mathrm{L}, 600 \mathrm{mg} / \mathrm{L}$ and $800 \mathrm{mg} / \mathrm{L}$, Adsorbent amount = $0.1 \mathrm{~g} / \mathrm{L}, \mathrm{pH}=7.11$, Stirring Speed $=300 \mathrm{rpm}$ ) adsorption data were used.

The first model used in the investigation of adsorption kinetics is the Pseudo 1st order kinetic equation. $\log$ (qe-qt) values were calculated from dye removal plots to time. Log (qe-qt) versus $\mathrm{t}$ graphics drawn at Figure 5, correlation coefficients $\left(\mathrm{R}^{2}\right)$ with $\mathrm{k}_{1}$ values were calculated from these graphs and shown in the Table $1 . \mathrm{K}_{1}$ values calculated as ; for Methylene Blue at a

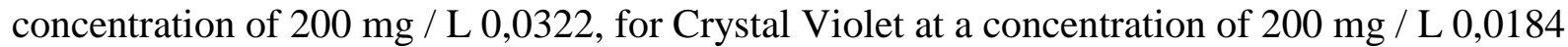
respectively. Correlation coefficient $\mathrm{R}^{2}$ calculated as 0,88 for Methylene Blue and 0,86 for Crystal Violet respectively. However, it was observed that the adsorption kinetics did not fit the Pseudo 1st order kinetic model because the calculated $\mathrm{q}_{\mathrm{e}}$ values with the experimental $\mathrm{q}_{\mathrm{e}}$ values did not match with each other.

In Pseudo 2nd order kinetic equation, $\mathrm{t} / \mathrm{qt}$ 'versus $\mathrm{t}$ graphs are drawn in Figure 4. From these graphs, $\mathrm{k}_{2}$ values and correlation coefficients $\left(\mathrm{R}^{2}\right)$ were calculated and shown in Table 1. Correlation coefficient $\mathrm{R}^{2}$ is; for Methylene Blue 0.99 at $200 \mathrm{mg} / \mathrm{L}$ and for Crystal Violet 0.99 at $200 \mathrm{mg} / \mathrm{L}$. Since the $\mathrm{q}_{\mathrm{e}}$ values calculated with the experimental $\mathrm{q}_{\mathrm{e}}$ values are compatible with each other, it was observed that the adsorption kinetics fit the Pseudo 2nd order kinetic model.

Finally, the Elovich equation is examined. As can be seen in Figure 3, Int graphs were drawn against $\mathrm{q}_{\mathrm{t}}$ values. From these graphs $\alpha$ and $\beta$ values and correlation coefficients $\left(\mathrm{R}^{2}\right)$ were calculated and shown in Table 1. However, since the correlation coefficients calculated from the graphs are low, it was observed that the adsorption kinetics did not fit the Elovich equation.

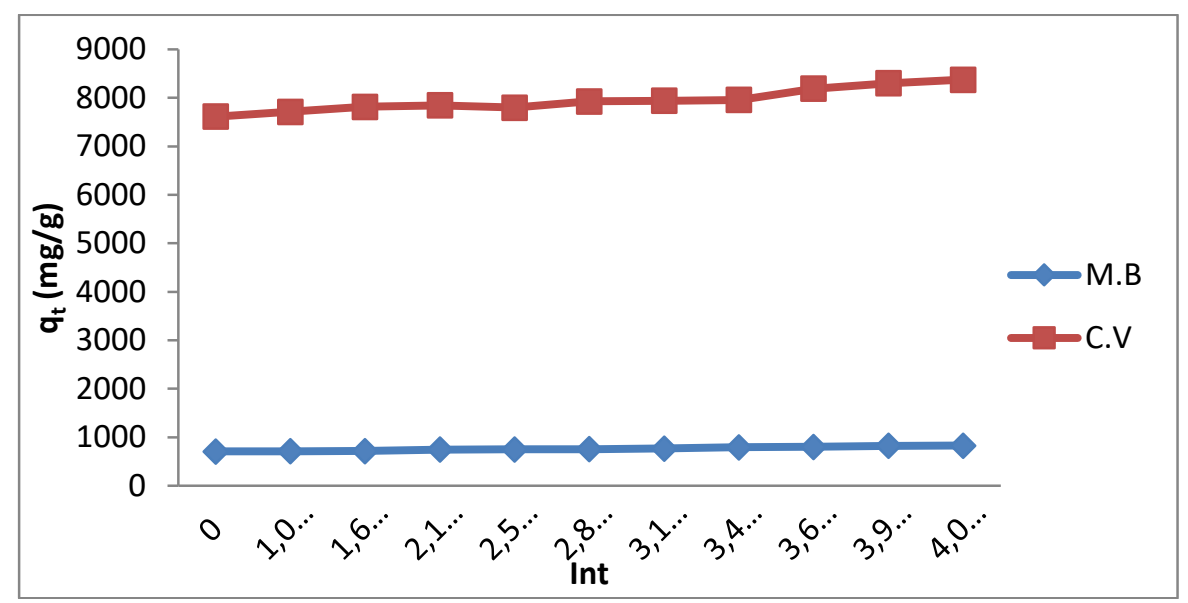

Figure 3. The Elovich equation for adsorption of $\mathrm{MB}$ and $\mathrm{CV}$ at different temperatures 


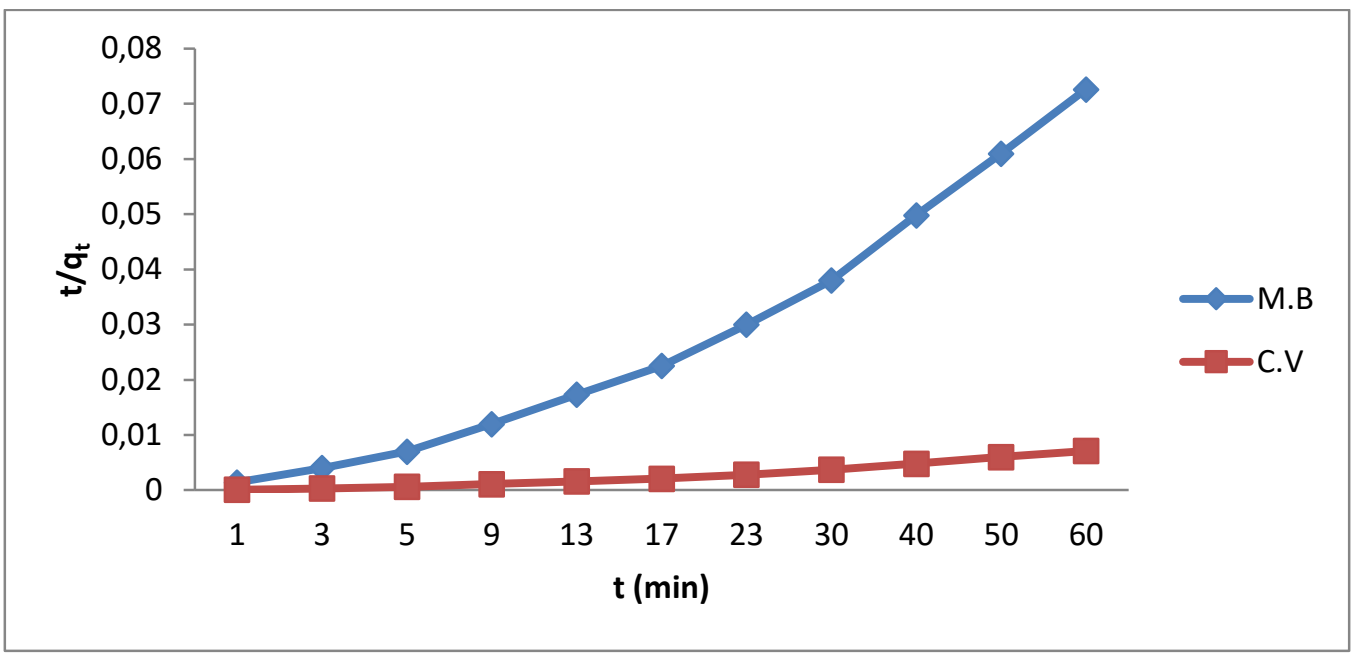

Figure 4. The pseudo-second-order adsorption kinetics of MB and CV at different temperatures

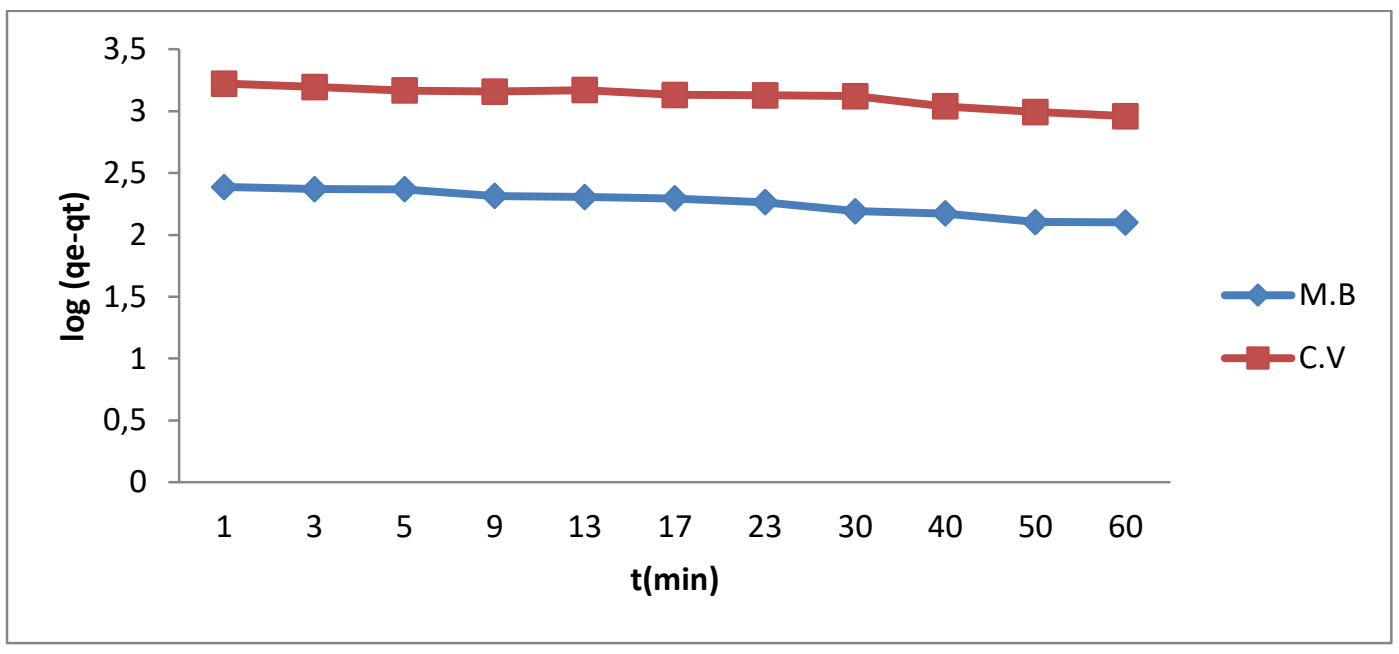

Figure 5. The pseudo-first-order adsorption kinetics of $\mathrm{MB}$ and $\mathrm{CV}$ at different temperatures

Table 1. Kinetic parameters for the effect of temperatures on the adsorption of MB and CV

\begin{tabular}{|c|c|c|c|c|c|c|c|c|c|c|c|}
\hline \multirow[t]{2}{*}{$\mathbf{T}(\mathbf{K})$} & \multirow[t]{2}{*}{$\begin{array}{l}\mathbf{q}_{\mathrm{e}}(\text { Exp. }) \\
(\mathrm{mg} / \mathrm{g})\end{array}$} & \multicolumn{3}{|c|}{$\begin{array}{l}\text { Pseudo 1st order kinetic } \\
\text { model }\end{array}$} & \multicolumn{3}{|c|}{$\begin{array}{l}\text { Pseudo } 2 \text { nd order kinetic } \\
\text { model }\end{array}$} & \multicolumn{3}{|c|}{ Elovich equation } & \multirow[t]{2}{*}{ Dye } \\
\hline & & $\begin{array}{l}\text { (qe)calc. } \\
(\mathrm{mg} / \mathrm{g})\end{array}$ & $\begin{array}{l}\mathrm{k} 1 \\
(1 / \mathrm{min})\end{array}$ & $\mathrm{R}^{2}$ & $\begin{array}{l}\text { (qe)calc. } \\
\text { (mg/g) }\end{array}$ & $\begin{array}{l}\mathrm{k} 1 \quad(\mathrm{~g} / \mathrm{mg} \\
\min )\end{array}$ & $\mathrm{R}^{2}$ & $\begin{array}{l}\alpha \\
\text { (mg/g } \\
\text { min) }\end{array}$ & $\begin{array}{l}\beta \\
(g / m g)\end{array}$ & $\mathrm{R}^{2}$ & \\
\hline 298 & 900.04 & 391.832 & 0.0322 & 0.88 & 909.09 & 0.00031 & 0.99 & 61.941 & 0.0215 & 0.73 & M.B \\
\hline 298 & 9285 & 1969.246 & 0.0184 & 0.86 & 10000 & 0.000005 & 0.99 & 72.9643 & 0.0035 & 0.72 & C.V \\
\hline
\end{tabular}




\subsection{Adsorption thermodynamics}

The effect of temperature on the Methylene Blue and Crystal Violet adsorption is shown in Figure 1. While the temperature increases, the percentage of dye removal increases lightly. The change in Standard free energy $(\Delta \mathrm{G})$, enthalpy $\left(\Delta \mathrm{H}^{\circ}\right)$ and entropy $\left(\Delta \mathrm{S}^{\circ}\right)$ of adsorption were calculated from the following equation:

$\Delta \mathrm{G}^{\circ}=-\mathrm{RT} \ln \mathrm{KC}$

Table 2. Thermodynamic parameters of MB ( $800 \mathrm{mg} / \mathrm{L})$

\begin{tabular}{|c|c|c|c|c|}
\hline $\mathbf{T}(\mathbf{K})$ & $\mathbf{l n K c}(\mathbf{k J} / \mathbf{m o l})$ & $\Delta \mathbf{G}^{\circ}(\mathbf{k J} / \mathbf{m o l})$ & $\Delta \mathbf{H}^{\circ}(\mathbf{J} / \mathbf{m o l} \mathbf{K})$ & $\Delta \mathbf{S}^{\circ}(\mathbf{J} / \mathbf{m o l} \mathbf{K})$ \\
\hline 298 & 1.864 & -4.565 & & \\
\hline 308 & 1.926 & -5.082 & 10.846 & 51.717 \\
\hline 318 & 2.151 & -5.600 & & \\
\hline
\end{tabular}

Table 3. Thermodynamic parameters of CV $(800 \mathrm{mg} / \mathrm{L})$

\begin{tabular}{|c|c|c|l|l|}
\hline $\mathbf{T}(\mathbf{K})$ & $\mathbf{l n K c}(\mathbf{k J} / \mathbf{m o l})$ & $\Delta \mathbf{G}^{\circ}(\mathbf{k J} / \mathbf{m o l})$ & $\Delta \mathbf{H}^{\circ}(\mathbf{J} / \mathbf{m o l ~ K})$ & $\Delta \mathbf{S}^{\circ}(\mathbf{J} / \mathbf{m o l} \mathbf{K})$ \\
\hline 298 & 1.720 & -4.3231 & & \\
\hline 308 & 1.991 & -5.0313 & 16.780 & 70.817 \\
\hline 318 & 2.164 & -5.7395 & & \\
\hline
\end{tabular}

where $R$ is gas constant, $K_{c}$ the equilibrium constant and $T$ is the temperature in $K$. The $K_{c}$ value is calculated from Eq. (5):

$K_{C}=\frac{C_{A}}{C_{S}}$

where $\mathrm{C}_{\mathrm{A}}$ and $\mathrm{C}_{\mathrm{S}}$ is the equilibrium concentration of dye ions on adsorbent $(\mathrm{mg} / \mathrm{L})$ and in the solution $(\mathrm{mg} / \mathrm{L})$, respectively.

Standard enthalpy $\left(\Delta \mathrm{H}^{\circ}\right)$ and entropy $\left(\Delta \mathrm{S}^{\circ}\right)$ of adsorption can be estimated from van't Hoff equation given in

$\ln K_{\mathrm{C}}=\frac{\Delta S^{\circ}}{R}-\frac{\Delta H^{\circ}}{R T}$

The slope and intercept of the van't Hoff plot is equal to $-\Delta H \% R T$ and $\Delta S \% R$, respectively. The van't Hoff plot for the adsorption of Methylene Blue and Crystal Violet onto Zivzik pomegranate is given in Figure 6 and Figure 7.

Thermodynamic parameters are summarized in Table 2 and Table 3.

It is seen in Table 2 and Table 3 that the $\Delta \mathrm{H}^{\circ}$ values were in $10.846 \mathrm{~kJ} / \mathrm{mol}$ for Methylene Blue and $16.780 \mathrm{~kJ} / \mathrm{mol}$ for Crystal Violet. The positive values of enthalpy change conform to the 
endothermic nature of the adsorption process. The positive values of $\Delta \mathrm{S}^{\circ}$ reflect the affinity of adsorbent material towards Methylene Blue and Crystal Violet. The entropy $\left(\Delta \mathrm{S}^{\circ}\right)$ values were $51.717 \mathrm{~J} / \mathrm{molK}$ for Methylene Blue and $70.817 \mathrm{~J} / \mathrm{molK}$ for Crystal Violet, respectively. Despite being endothermic nature, the spontaneity of the adsorption process was decreased in the Gibbs energy of the system. The $\Delta \mathrm{G}^{\circ}$ values varied in range with the mean values showing a gradual increase from 1.864 to $2.151 \mathrm{~kJ} / \mathrm{mol}$ for Methylene Blue and 1.720 to $2.164 \mathrm{~kJ} / \mathrm{mol}$ for Crystal Violet, respectively, in the temperature range of $25-45^{\circ} \mathrm{C}$ by endothermic nature of the adsorption process.

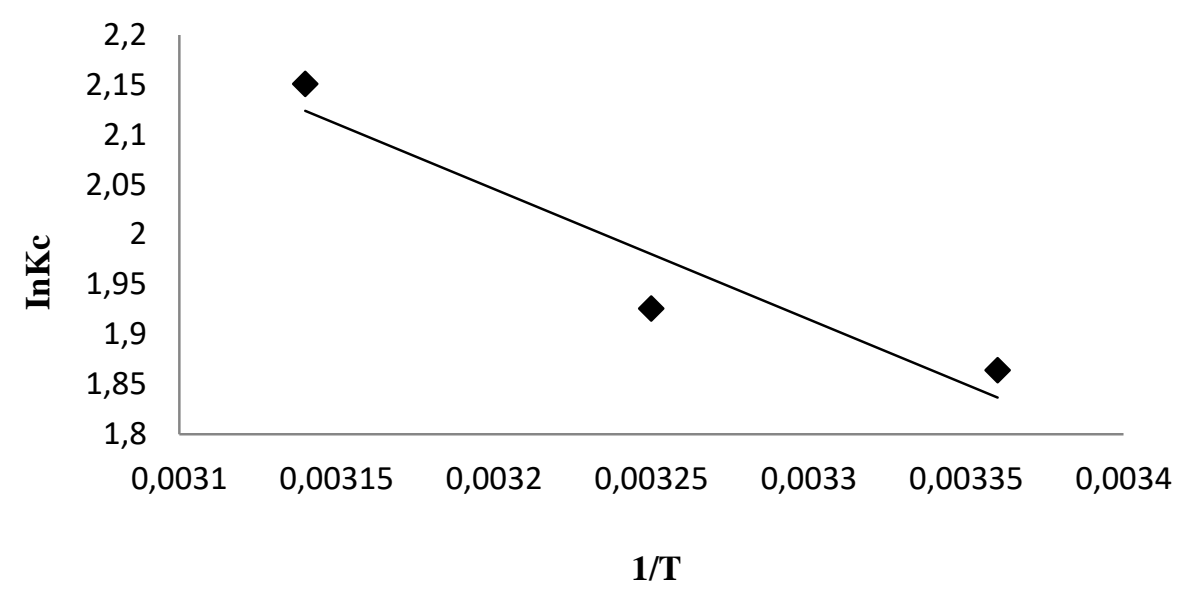

Figure 6. Van't Hoff plots of MB adsorption onto activated carbon from Zivzik pomegranate for $800 \mathrm{mg} / \mathrm{L}$

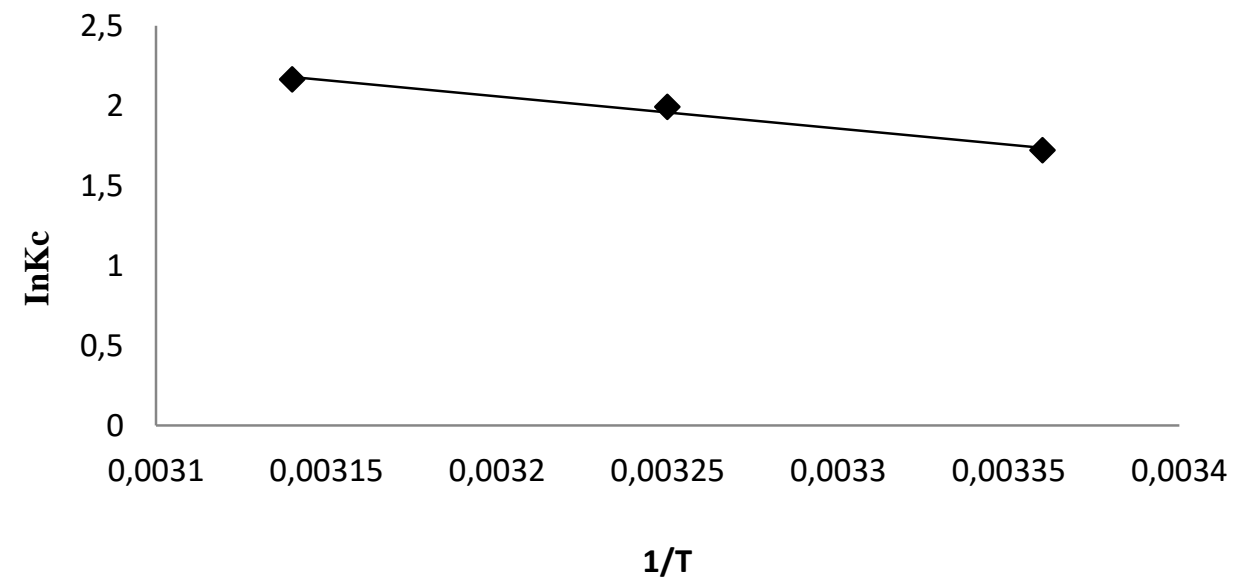

Figure 7. Van’t Hoff plots of CV adsorption onto activated carbon from Zivzik pomegranate for $800 \mathrm{mg} / \mathrm{L}$ 


\section{CONCLUSIONS}

The results of this work can be summarized as follows :

- The $\mathrm{N}_{2}$ adsorption isotherm of Zivzik Pomegranate is of type IV. The values of $\mathrm{S}_{\mathrm{BET}}, \mathrm{V}_{\mathrm{t}}$ and $\mathrm{S}_{\mathrm{t}}$ are $1513,05 \mathrm{~m}^{2} / \mathrm{g}, 0,59 \mathrm{~cm}^{3} / \mathrm{g}$ and $429,044 \mathrm{~m}^{2} / \mathrm{g}$ respectively. Results show that activated carbon includes micropores and mesopores.

- When the adsorption isotherm models for Methylene Blue were examined, it was found to be suitable for the Langmuir model. The constants obtained by the Langmuir equilibrium model have been examined. $\mathrm{R}_{\mathrm{L}}$ value, which is the dimensionless separation factor found using $\mathrm{K}_{\mathrm{L}}$ value from Langmuir parameters, was found to be 0.001 . This result shows that the adsorption process is efficient. In addition, it was seen that the correlation factor $\mathrm{R}^{2}$ calculated from the graph drawn according to the Langmuir isotherm has a high value such as 0,999 . When the adsorption isotherm models for Crystal Violet are examined, their suitability to the Langmuir model was determined. Constants obtained by the Langmuir equilibrium model have been examined. $\mathrm{R}_{\mathrm{L}}$ value, which is the dimensionless separation factor found using $\mathrm{K}_{\mathrm{L}}$ value from Langmuir parameters, was found to be 0.001 . This result shows that the adsorption process is efficient. It was seen that the correlation factor $\mathrm{R}^{2}$ calculated from the graph drawn according to the Langmuir isotherm has a high value such as 0,999 . In addition, the correlation factor $\mathrm{R}^{2}$ calculated from the graphs drawn according to the Freundlich and Temkin isotherms for Crystal Violet was found to be 0.910 and 0.913 , respectively. This shows that the Crystal Violet dye is also suitable for Freundlich and Temkin isotherm models.

- For the Methylene Blue and Crystal Violet dyestuffs, the system's compliance with the adsorption rate expressions was investigated by making use of the time-dependent variation of the amount adsorbed on activated carbon at different temperatures. When comparing the results of the Pseudo 1st Order kinetic model, Pseudo 2nd Order kinetic model and Elovich kinetic models, it was determined that the Pseudo 2nd Order kinetic model was more appropriate. It has been observed that the correlation factor $\mathrm{R}^{2}$ calculated from the graphs drawn using the Pseudo 2nd order kinetic model is greater than the $\mathrm{R}^{2}$ calculated from the graphs drawn using other kinetic models.

\section{REFERENCES}

[1] Kuyucu A.E., (2013). Characterıation of activated carbon obtained from Zivzik Pomegranate (Siirt) and adsorption of dye, Master's Thesis, Yüzüncü Y1l University, Department of Primary Education, Van.

[2] Önal, Y., (2006). Kinetics of adsorption of dyes from aqueous solution using activated Carbon prepared from waste apricot, Journal of Hazardous Materials B, 137: 1719-1728.

[3] Saygilı H., (2015). The production of nano-porous activated carbon from some vegatable pulps and investigation of avallability in some adsorption practıces, Phd Thesis, Dicle University, Institute of natural and applied sciences department of chemistry, Diyarbakır 
[4] Selçuk, A., Kuyucu, A. E., Kul, A.R, Önal, G., (2015). Investıgatıon of Isothermal Parameters of Dye Adsorption onto Active Carbon, International Journal of Ecosystems And Ecology Sciences, Albania.

[5] R.C. Bansal, M. Goyal (1992). Activated carbon adsorption, CRC pres,.

[6] Enver Y. K. (2004). Ticari aktif karbon üretimi ve özelliklerinin belirlenmesi, Dokuz Eylül Mühendislik Bilimleri Dergisi, İzmir.

[7] J.W. Hassler, Activated carbon, (1951). ChemicalPub, Co.

[8] R. Wirasnita, (2014). Removal of bisphenol A from aqueous solution by activated carbon derived from oil palmempty fruit bunch, Water, Air, \& SoilPollution, 225(10), p. 2148.

[9] Sarıcı-Özdemir Ç., Önal Y., (2010). Study to investigate the importance of mass transfer of naproxen sodium onto activated carbon, Chemical Engineering and Processing, 49: 1058-106.

[10] Vardin H., Karaaslan M., Yılmaz F. M., (2011). Zivzik ve görümlü narlarının özelliklerinin ve katma dĕgerli ürünlere işlenebilirliğinin belirlenmesi, Harran University, Siirt.

[11] Lagergren, S., (1898). Zurtheorie der sogenannten adsorption gelösterstoffe, Kungliga Svenska Vetenskaps akademiens, Handlingar, pp. 1-39.

[12] Ma, X.,Li, L., Yang, L., Su, C., Wang, K., Yuan, S., Zhou, J., (2012). Adsorption of heavy metal ions using hierarchical $\mathrm{CaCO}_{3}$-maltose meso/macro porous hybrid materials: Adsorption isotherms and kinetic studies.

Journalof Hazardous Materials, 209-210:467-477.

[13] Elovich, S.Y.,Larionov, O.G., (1962). Theory of adsorption from solutions of non electrolytes on solid (I) equation adsorption from solutions and the analysis of its simplest form (II), verification of the equation of adsorption isotherm from solutions, Izv. Akad. Nauk. SSSR, 209-216.

[14]Tunalı, S., Akar, T., Özcan, A.S., Kıran, İ., Özcan, A., (2006). Equilibrium and kinetics of biosorption of lead(II) from aqueous solutions by Cephalosporiumaphidicola, Separation and Purification Technology, 47: 105112.

[15] Tunalı, S., Akar, T., (2006). Zn(II) biosorption properties of Botrytisc in area biomass, Journal of Hazardou sMaterials, 131: 137-145.

[16] Selçuk A., Kuyucu A. E., Kul A.R., Ocak S., (2014). Adsorption of dye on to activated carbon obtained from Zivzik Pomagranate, International Environmental Sciences Symposium of Van, Van. 